University of California, Hastings College of the Law UC Hastings Scholarship Repository

Faculty Scholarship

2018

\title{
California's Drug Transparency Law: Navigating the Boundaries of State Authority on Drug Pricing
}

Jaime S. King

UC Hastings College of the Law, kingja@uchastings.edu

Katherine L. Gudiksen

Timothy T. Brown

Christopher M. Whaley

Follow this and additional works at: https://repository.uchastings.edu/faculty_scholarship

\section{Recommended Citation}

Jaime S. King, Katherine L. Gudiksen, Timothy T. Brown, and Christopher M. Whaley, California's Drug Transparency Law: Navigating the Boundaries of State Authority on Drug Pricing, 37 Health Aff. 1503 (2018).

Available at: https://repository.uchastings.edu/faculty_scholarship/1687 


\section{California's Drug Transparency Law: Navigating The Boundaries Of State Authority On Drug Pricing}

ABSTRACT The California drug transparency bill (SB-17), signed into law in October 2017, seeks to promote transparency in pharmaceutical pricing, enhance understanding about pharmaceutical pricing trends, and assist in managing pharmaceutical costs. This article examines the legal and regulatory aspects of SB-17, explores legal challenges to the law, compares it to other state efforts to address rising drug prices, and discusses how California can maximize the impact of SB-17 by coupling the law with other incentives. While SB-17 might not significantly reduce drug prices, the new law represents a meaningful step for one state seeking to negotiate the political and legal boundaries of state action to rein in drug prices.

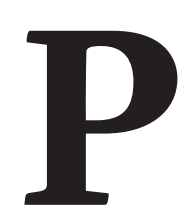
rescription drug spending per capita is far higher in the United States than in other high-income countries, exceeding $\$ 1,000$ per person in 2016. ${ }^{1}$ The rate of spending growth for retail prescription drugs has declined significantly (from 8.9 percent in 2015 to 1.3 percent in 2016), ${ }^{2}$ but prescription drug costs remain a financial burden for many people. In a 2016 national survey, 20 percent of adults reported that they had not filled a drug prescription in the past year because of cost. ${ }^{3}$ Moreover, for many people, price shopping for prescription drugs remains a challenge. ${ }^{4,5}$ In a 2017 poll, voters ranked prescription drug prices and out-ofpocket spending as far more important than any other health policy issue, including fixing the Affordable Care Act. ${ }^{6}$

Following the recent outcry about the affordability of prescription drugs, Congress has held hearing $s^{7}$ and introduced bills ${ }^{8-10}$ attempting to make prescription drugs more affordable-with negligible success. In response, many state legislatures have taken up the mantle of controlling prescription drug spending. In 2018, forty-four states introduced and twenty-nine states passed legislation designed to increase the accessibility and affordability of prescription medications. ${ }^{11}$ States have sought to increase price transparency, prevent "excessive" price increases, regulate pharmacy benefit managers, and allow drug importation from Canada. ${ }^{11}$ Fulfilling its role as an innovator state, California has led the way toward price transparency. In October 2017 Gov. Jerry Brown signed Senate Bill 17 (SB-17), a bill that seeks to improve drug price transparency and improve price negotiations by requiring specific disclosures from pharmaceutical manufacturers and health insurers.

In the absence of federal action, states have recently proposed an array of methods to regulate drug prices, but the boundaries of state power to regulate pharmaceutical prices remain vague. In addition, any state that passes new legislation should expect a formidable legal challenge from the pharmaceutical industry. In a setback for states hoping to address rising drug prices, the Fourth Circuit Court of Appeals declared a Maryland law prohibiting price gouging for generic medications ${ }^{12}$ unconstitutional because it violated the dormant commerce clause, which bans states from unduly burdening interstate commerce. ${ }^{13}$ In light of that ruling and the uncertainty about the limits of state action, the
DOI: $10.1377 /$ hlthaff.2018.0424 HEALTH AFFAIRS 37, NO. 9 (2018): 1503-1508 (c)2018 Project HOPEThe People-to-People Health Foundation, Inc.
Katherine L. Gudiksen is a senior research fellow at the Source on Healthcare Price and Competition, University of California Hastings College of the Law, in San Francisco.

Timothy T. Brown is an associate professor of health economics, School of Public Health, University of

California Berkeley.

Christopher M. Whaley is an associate policy researcher at the RAND Corporation in Santa Monica, California.

Jaime S. King (kingja@ uchastings.edu) is a professor of law at the University of California Hastings College of the Law and executive editor of the Source on Healthcare Price and Competition. 
precedents that will be set in legal challenges to SB-17 may help resolve questions about states' power and serve as a foundation for other states looking to pass meaningful legislation to address rising drug costs. This commentary examines the provisions of SB-17, discusses the potential legal challenges to it, and finds that SB-17, while carefully crafted to avoid many preemption issues, may have limited impact unless it is coupled with other policies.

\section{Requiring Pricing Disclosure}

To promote transparency in pharmaceutical pricing, enhance understanding about pricing trends, and assist payers in the management of pharmaceutical costs, SB-17 requires insurers and manufacturers to disclose information on several aspects of pricing. Companies that fail to comply face civil penalties.

Disclosures BY INSURERS Health plans that file annual rate information with the California Department of Managed Health Care or Department of Insurance must submit an additional annual report that names the twenty-five most frequently prescribed drugs, the twenty-five most costly drugs in terms of total annual spending, and the twenty-five drugs with the greatest increase in total annual spending. ${ }^{14}$ In addition, large employer group plans must specify the portion of premiums attributable to prescription drugs and designate the proportion of any premium increase due to prescription costs versus other sources (for example, inpatient care, outpatient care, and physician services). SB-17 also requires these two departments to report aggregated information to state legislators and the public and to hold public meetings to discuss their findings. However, with the exception of reported aggregated information, the agencies must keep SB-17 disclosures confidential.

Disclosures by manufacturers SB-17 requires pharmaceutical manufacturers to notify purchasers at least sixty days before any price increase that exceeds 16 percent over a two-year period for all drugs with a wholesale acquisition cost greater than $\$ 40 .{ }^{15}$ Federal law defines this cost as the manufacturer's list price for the drug to wholesalers or direct purchasers in the United States, not including rebates or other discounts. ${ }^{16}$ In addition, manufacturers must notify the California Office of Statewide Health Planning and Development about any newly marketed pharmaceutical with a wholesale acquisition cost above the threshold of a specialty drug under Medicare Part D (more than $\$ 670$ per month). ${ }^{17}$ Manufacturers must also provide the office with information on the drug's usage (for example, indication and dosage), the factors used to determine the wholesale acquisition cost, and marketing materials. However, the law limits disclosure requirements to information already in the public domain, which provides little additional transparency.

Overall, these provisions will provide policy makers with information that might otherwise be difficult to collect and aggregate. However, their real value lies in their ability to help shape the scope of state legal boundaries surrounding drug pricing reform.

\section{Challenges In State Regulation Of Drug Prices}

The pharmaceutical industry has consistently challenged states' attempts to promote price transparency and regulate price increases. In fact, the contours of SB-17 appear designed to avoid pitfalls encountered by other states in their attempts to constrain drug prices, including preemption by the federal Employee Retirement Income Security Act (ERISA) of 1974 and violations of trade-secret laws.

EMPLOYEE RETIREMENT INCOME SECURITY ACT PREEMPTION ERISA creates significant barriers to state health reform efforts that affect employee benefit plans, including prescription drug coverage. With the goal of establishing uniformity across states, ERISA establishes minimum standards for employee pension and benefit plans and preempts the ability of states to pass laws that "relate to" employee benefit plans. ${ }^{18}$ While ERISA exempts state insurance regulations from this preemption, it does not deem self-insured employer benefits to be insurance, and therefore it preempts any state attempt to pass legislation that relates to self-insured employer plans-which cover approximately 60 percent of Americans with employer-sponsored insurance. ${ }^{19,20}$

As a result, ERISA has had severe consequences for states' attempts to control health care costs and improve price transparency. In 2016 the US Supreme Court ruled in Gobeille v. Liberty Mutual Insurance Co. that Vermont could not require selfinsured employers to report their health care claims data to the state all-payer claims database, because such reporting impermissibly intrudes on central matters of ERISA plan administration. ${ }^{21}$ Indeed, citing Gobeille, the Eighth Circuit Court of Appeals held that ERISA preempted the application of an Iowa law-which required pharmacy benefit managers to disclose how they priced generic medications to the state insurance commissioner-from applying to managers that served ERISA plans. ${ }^{22}$ As a result, ERISA has become a powerful barrier to several forms of health care price transparency legislation, be- 


\section{The contours of SB-17 appear designed to avoid pitfalls encountered by other states in their attempts to constrain drug prices.}

cause states must choose between passing laws that will not benefit a large section of the population (those with self-insured employer-based coverage) and risking being dragged through an uncertain, and currently unfavorable, legal battle over the scope of ERISA preemption. ${ }^{23}$

SB-17 attempts to avoid ERISA preemption by requiring disclosures only from plans regulated by the Department of Managed Health Care or the Department of Insurance, which includes large and small employer group plans but not plans of self-insured employers. As a result, lawmakers will not have pharmaceutical spending data for the employees of some of the largest employers in the state when considering other measures to address drug prices.

TRADE SECRETS The pharmaceutical industry has also challenged states' efforts to increase price transparency for violating federal and state trade-secret laws. ${ }^{24}$ In 2017 Nevada passed Senate Bill 539, which required manufacturers of "essential" diabetes drugs to provide information to the state that included the costs of manufacturing and marketing the drugs and the amount of profits attributed to them. In addition, if a manufacturer increases the wholesale acquisition cost by more than the rate of medical inflation, it must provide the Nevada Department of Health and Human Services with an explanation of the factors that contributed to the increase and the percentage of the total increase in price that is attributable to each factor. Nevada's law also amended the state's definition of a trade secret to specifically exclude any information that the law requires, so that the state can publish the information. Following a civil suit, ${ }^{24}$ however, filed by the trade organizations that represent the interests of pharmaceutical and biotechnology companies-Pharmaceutical Research and Manufacturers of America (PhRMA) and Biotechnology Innovation Organization
(BIO) - Nevada's Department of Health and Human Services issued regulations that allow pharmaceutical manufacturers or pharmacy benefit managers to request confidentiality of the information submitted to the state. ${ }^{25}$ The state will keep confidential any information it reasonably considers to meet the standards of a trade secret under the federal Defend Trade Secrets Act of 2016 (18 US Code, section 1836) or Exemption 4 of the federal Freedom of Information Act [5 US Code, section 552(b)(4)].

In contrast to the Nevada law, SB-17 attempts to avoid violating trade-secrets protections by limiting required disclosures to publicly available information or requiring disclosures to agencies (such as the Office of Statewide Health Planning and Development) that must keep the information confidential. While the wholesale acquisition cost is publicly available, it remains unclear whether advance notification of an impending increase above a threshold-such as that required by SB-17-constitutes a trade secret.

\section{Challenges To SB-17}

Unlike legislation in other states, SB-17 does not specifically limit price increases or allow state officials to intervene if they believe a manufacturer has engaged in price gouging. At the most fundamental level, SB-17 simply requires drug manufacturers to provide both advance warning of price increases above a threshold and detailed information about newly marketed specialty drugs. Nonetheless, in December 2017 PhRMA filed suit in the District Court for the Eastern District of California, challenging SB-17 for violating the dormant commerce clause and the First and Fourteenth Amendments. ${ }^{26}$

dormant commerce clause The Constitution gives Congress the power to regulate interstate commerce, and the dormant commerce clause is a long-standing judicial interpretation that prohibits states from passing laws that discriminate against or excessively burden interstate commerce without sufficient offsetting local benefits. ${ }^{27}$ In Healy v. Beer Institute the Supreme Court held that the externality principle of the dormant commerce clause forbids states from directly regulating commerce that occurs outside of the regulating state, "regardless of whether the statute's extraterritorial reach was intended by the legislature." 28

PhRMA alleges that SB-17 violates the dormant commerce clause because it requires advance notice of increases to the wholesale acquisition cost, thereby delaying price increases in external markets. Under SB-17 a manufacturer cannot increase the wholesale acquisition cost without 
waiting sixty days or facing financial penalities. ${ }^{26}$ Therefore, because contract prices with wholesalers, hospitals, pharmacies, pharmacy benefit managers, payers, and others are typically based on the wholesale acquisition cost, PhRMA asserts that SB-17 becomes an unconstitutional nationwide ban on price increases for certain drugs, unless the State of California receives sixty-day advance notification. ${ }^{26}$

Until recently, many courts narrowly interpreted the externality principle to strike down only laws that controlled prices or required price affirmation, linked in-state prices to those charged elsewhere, or raised costs for outof-state consumers or rival businesses. ${ }^{29}$ In April 2018, however, a three-judge panel of the Fourth Circuit Court of Appeals interpreted the principle more broadly to find that Maryland's law prohibiting price gouging for essential offpatent or generic drugs ${ }^{12}$ violated the dormant commerce clause. The court held that because the law applied to drugs "made available for sale within the state," it could apply to drugs that were never actually sold in Maryland. The court reasoned that the law is "effectively a price control statute that instructs manufacturers and wholesale distributors as to the prices they are permitted to charge in transactions that do not take place in Maryland. ${ }^{\text {"13 }}$ In July 2018 the Fourth Circuit Court of Appeals denied the state's petition to have the case reheard by the entire court, but Judge Wynn issued a dissent, ${ }^{30}$ likely setting up an appeal to the Supreme Court.

In contrast to Maryland's anti-price gouging law, ${ }^{12} \mathrm{SB}-17$ requires only advance notice of price increases and allows increases of any size (with proper notification). Furthermore, significant legal uncertainty surrounds the interpretation of the dormant commerce clause, and a decision by the Fourth Circuit Court of Appeals on the Maryland law is not binding on the PhRMA case against SB-17 in the District Court for the Eastern District of California. Given these realities, it is not clear how the District Court will rule. Nonetheless, the District Court's decision on SB-17 will likely have significant implications for other challenges to drug pricing legislation.

FREE SPEECH AND DUE PROCESS In addition to its dormant commerce clause claim, PhRMA argues that SB-17 violates pharmaceutical manufacturers' First Amendment right to free speech and their Fourteenth Amendment right to due process. ${ }^{26} \mathrm{PhRMA}$ alleges that SB-17 violates the First Amendment when it singles out manufacturers as the only entity that must give advance notice of pharmaceutical price increases, when other entities, such as pharmacy benefit managers, also affect prices. PhRMA also argues that SB-17 unnecessarily requires manufacturers to
SB-17 will have minimal impact unless the state takes additional measures to address rising drug prices.

justify a price increase using only two potential justifications: a "change or improvement" in the drug. The law does not consider other typical justifications for price increases (such as raising capital for research or providing increasing value to the health system by decreasing overall spending), which essentially forces manufacturers to provide a false reason or abstain from answering the question. Finally, PhRMA claims that SB-17 violates the due process clause of the Fourteenth Amendment because it does not specify whether wholesale acquisition cost increases before January 1, 2018, would trigger SB-17's reporting requirements-which would make the law retroactive. ${ }^{26}$ While California could remedy this potential violation by considering only prospective price increases, the state appears poised to apply the requirement retrospectively, pending a ruling in PhRMA's lawsuit.

To pass effective legislation, state lawmakers need clear signals from the courts regarding the boundaries of state regulation of all health care prices, including pharmaceutical prices. Thus, SB-17 represents an important effort by a state looking to pass meaningful legislation that will withstand legal challenges by the pharmaceutical industry and help define the contours of permissible state action. Nonetheless, SB-17 will have minimal impact unless the state takes additional measures to address rising drug prices.

\section{Implications Of SB-17 For Drug Pricing}

Shortly after its passage, SB-17 was dubbed "the nation's most comprehensive law aimed at shining a light on prescription drug prices." ${ }^{31}$ While the law makes significant strides, the crafting of SB-17 to avoid preemption pitfalls constrains its reach in several ways. Indeed, SB-17 may have unintended consequences, including speculation in the pharmaceutical supply chain, price collusion, and artificial shortages. 
UNINTENDED CONSEQUENCES First, the law will do little to directly reduce drug prices overall, because pharmaceutical manufacturers can spread price increases out across drug categories and adjust rebates to maintain profits. The law relies on the wholesale acquisition cost to avoid trade-secret issues, but as a result, it does not include information on confidential rebates and price discounts provided to pharmacy benefit managers, which often dramatically alter the actual prices. SB-17 thus leaves open several avenues for price manipulation.

Second, SB-17's advance notice requirement provides useful information for direct purchasers, policy makers, and insurers, but it also creates opportunities for market manipulation. For instance, it gives drug manufacturers the opportunity to raise their prices in concert. If a manufacturer of a competing drug receives advance notice of a competitor's price increase, it could commensurately increase the price of its drug with minimal risk of losing sales to the competition. ${ }^{32,33}$ In turn, SB-17 could allow competing firms to signal their intent to increase prices, which could lead to tacit price collusion.

Third, SB-17 encourages pharmacies to stockpile drugs when they receive notice of a pending price increase. ${ }^{34}$ Distribution service agreements between manufacturers and wholesalers generally limit the amount of inventory that a wholesaler can hold, but pharmacies are not typically bound by similar contracts. As a result, when pharmacies-especially those affiliated with or owned by a pharmacy benefit manager or an insurer-receive sixty days' advance notice, they can purchase extra inventory at the lower price but sell at a higher price later. ${ }^{34}$ Such stockpiling can create artificial shortages for pharmacies that do not receive advance notice. The pending merger between Aetna, an insurer, and CVS Health, a pharmacy group with an embedded pharmacy benefit manager, may exacerbate such effects.

multiple strategies needed Despite the potential for unintended consequences and other limitations in SB-17, the law represents a meaningful initial step in determining what power states have to address the affordability of prescription drugs. Transparency alone, however, is insufficient to encourage patients to priceshop. Research on online price transparency initiatives finds only modest changes in patient behavior, ${ }^{35,36}$ but combining price transparency with targeted consumer incentives can lead to widespread price-shopping. ${ }^{37}$ Augmenting price transparency information with a tangible financial incentive, such as reference pricing, has been found to be effective in reducing pharmaceutical spending and is a viable next step in drug pricing policy. ${ }^{38}$

\section{Conclusion}

California's SB-17 constitutes a critical part of a movement by states to reduce pharmaceutical prices and clarify the scope of states' power to address health care prices more generally. Although it is innovative, SB-17 is unlikely to have a significant impact on drug spending without additional incentives for consumers to use lower-priced drugs. Nonetheless, the law remains a vital step in defining state authority and reflects California's status as a leader among states looking to control prescription drug prices.

\section{NOTES}

1 Sarnak DO, Squires D, Bishop S. Paying for prescription drugs around the world: why is the U.S. an outlier? [Internet]. New York (NY): Commonwealth Fund; 2017 Oct 5 [cited 2018 Jul 10]. Available from: http://www.commonwealthfund .org/publications/issue-briefs/ 2017/oct/prescription-drug-costsus-outlier

2 Hartman M, Martin AB, Espinosa N, Catlin A, National Health Expenditure Accounts Team. National health care spending in 2016: spending and enrollment growth slow after initial coverage expansions. Health Aff (Millwood). 2018;37(1):150-60.

3 Osborn R, Squires D, Doty MM, Sarnak DO, Schneider EC. In new survey of eleven countries, US adults still struggle with access to and affordability of health care. Health Aff (Millwood). 2016;35(12): 2327-36.
4 Arora S, Sood N, Terp S, Joyce G. The price may not be right: the value of comparison shopping for prescription drugs. Am J Manag Care. 2017; 23(7):410-5.

5 Kullgren JT, Segel JE, Peterson TA, Fendrick AM, Singh S. Availability and variation of publicly reported prescription drug prices. Am J Manag Care. 2017;23(7):444-8.

6 Rovner J. Drug prices, not the health law, top voters' health priorities for 2017. Kaiser Health News [serial on the Internet]. 2016 Oct 27 [cited 2018 Jul 10]. Available from: https:// khn.org/news/drug-prices-notthe-health-law-top-voters-healthpriorities-for-2017/

7 US Senate Special Committee on Aging. Sudden price spikes in offpatent prescription drugs: the monopoly business model that harms patients, taxpayers, and the U.S health care system [Internet].
Washington (DC): US Senate; 2016 Dec [cited 2018 Jul 10]. Available from: https://www.aging.senate .gov/imo/media/doc/Drug\%20 Pricing\%20Report.pdf

8 The Creating and Restoring Equal Access to Equivalent Samples Act (CREATES) of 2017, HR 2212, 115th Cong. (2017).

9 The Improving Access to Affordable Prescription Drugs Act of 2017, HR 1776 and S 771, 115th Cong. (2017).

10 The Creating Transparency to Have Drug Rebates Unlocked (C-THRU) Act of 2017, S 637, 115th Cong. (2017).

112018 pharmaceutical legislation. The Source on Healthcare Price and Competition [serial on the Internet]. c 2014-18 [cited 2018 Aug 15]. Available from: http://sourceon healthcare.org/pharmaceuticals

12 Price gouging in sale of an essential off-patent or generic drug prohib- 
ited. Md. Code Ann., Health-Gen. Sect. 2-802(a).

13 Association for Accessible Medicines v. Frosh. Case 1:17-cv-01860-MJG. 2017 WL 4347818 (D. Md. Sept 29, 2017).

14 California Code, Health and Safety Code-HSC Sect. 1367.243.

15 California Code, Health and Safety Code-HSC Div. 107 Part 2 Sect. 127677.

1642 U.S.C. Sect. $1395 w-3 a(c)(6)$ (B).

17 Medicare defines specialty drugs as those in which the majority of prescriptions for that drug cost more than a specified threshold and allows plans to charge higher cost sharing for drugs in the specialty tier than for those in other tiers. 42 C.F.R. Sect. 423.578(a) (7).

1829 U.S.C. Sect. 1144(a)(2018).

19 Fuse Brown EC, Sarpatwari A. Removing ERISA's impediment to state health reform. N Engl J Med. 2018; 378(1):5-7.

20 Henry J. Kaiser Family Foundation, Health Research and Educational Trust. Employer health benefits: 2017 annual survey [Internet]. San Francisco (CA): KFF; 2017 Sep 19. Section 10, Plan funding; [cited 2018 Jul 26]. Available from: https:// www.kff.org/report-section/ehbs2017-section-10-plan-funding/

21 Gobeille v. Liberty Mutual Insurance Co., 136 S.Ct. 936 (2016).

22 Pharmaceutical Care Management Association v. Gerhart, 852 F.3d 722 (8th Cir., 2017).

23 Fuse Brown E, King J. The consequences of Gobeille v. Liberty Mutual for health care cost control. Health Affairs Blog [blog on the Internet]. 2016 Mar 10 [cited $2018 \mathrm{Jul}$ 10]. Available from: https://www .healthaffairs.org/do/10.1377/hblog 20160310.053837/full/

24 PhRMA v. Sandoval. Complaint for Declaratory and Injunctive Relief. Case 2:17-cv-02315 Filed 09/01/17.

25 Nevada Department of Health and Human Services. Approved regulation of the Department of Health and Human Services, LCB File No. R042 18, effective May 31, 2018 [Internet]. Carson City (NV): DHHS; [cited 2018 Aug 7]. Available from: http:// dhhs.nv.gov/uploadedFiles/ dhhsnvgov/content/HCPWD/Sec $\% 20$ of\%20State\%200fficial(1).pdf

26 PhRMA v. Brown. Complaint for Declaratory and Injunctive Relief. Case 2:17-at-01323. Filed 12/8/17.

27 Pike v. Bruce Church, Inc., 90 S.Ct. 844 (1970).

28 Healy v. Beer Institute, 109 S.Ct. 2491 (1989).

29 Energy \& Env't Legal Inst. v. Epel, 793 F.3d 1169 (10th Cir. 2015).

30 Association for Accessible Medicines v. Frosh. Case 1:17-cv-01860-MJG. 2018 WL 3574755 (D. Md. Sept 29, 2017).

31 Seipel T. California Assembly passes drug price transparency bill. Mercury News [serial on the Internet]. 2017 Sep 11 [cited 2018 Jul 10]. Available from: https://www .mercurynews.com/2017/09/11/ california-assembly-passes-drug- price-transparency-bill/

32 Farrell J. Cheap talk, coordination, and entry. Rand J Econ. 1987;18(1): 34-9.

33 Albæk S, Møllgaard P, Overgaard P. Government-assisted oligopoly coordination? A concrete case. J Ind Econ. 1997;45(4):429-43.

34 Fein AJ. Thanks, California! SB-17 will trigger massive speculative buying, windfall pharmacy profits, and supply chain disruption. Drug Channels [serial on the Internet]. 2017 Oct 11 [cited 2018 Jul 10]. Available from: https://www .drugchannels.net/2017/10/thankscalifornia-SB-17-will-trigger.html

35 Whaley C, Schneider Chafen J, Pinkard S, Kellerman G, Bravata D, Kocher R, et al. Association between availability of health service prices and payments for these services. JAMA. 2014;312(16):1670-6.

36 Desai S, Hatfield LA, Hicks AL, Sinaiko AD, Chernew ME, Cowling $\mathrm{D}$, et al. Offering a price transparency tool did not reduce overall spending among California public employees and retirees. Health Aff (Millwood). 2017;36(8):1401-7.

37 Whaley C, Brown T, Robinson J. Consumer responses to price transparency alone versus price transparency combined with reference pricing. Am J Health Econ. 2018 Mar 5. [Epub ahead of print].

38 Robinson JC, Whaley CM, Brown TT. Association of reference pricing with drug selection and spending. N Engl J Med. 2017;377(7):658-65. 